\title{
Opinions \& Suggestions of Farmers in Adoption of Intercrop in Sugarcane from Kolhapur District
}

Bhingardeve S. D.

Senior Research Assistant, Regional Sugarcane \& Jaggery

Research Station, Kolhapur, Maharashtra, India
B. T. Kolgane

Associate Professor of Agriculture Extension, College of Agriculture, Kolhapur, Maharashtra, India
D. P. Deshmukh

Assistant Professor of Plant

Pathology, College of Agriculture, Kolhapur, Maharashtra, India

\section{ABSTRACT}

The extension research was conducted in college development block of Agriculture College, Kolhapur in the year 2016. From this study, it was Indicated that with respect to intercropping in sugarcane, respondents were preferred the vegetable crop as intercrop (60.00 per cent). Majority of the respondents mentioned there was no any harmful effect of intercrop on main crop followed by intercrops helps in maintains soil fertility. It is observed that most of the respondents were remarked constraints of increase in earthing-up period (98.00 per cent) and first earthingup and intercultural operations are not possible $(94.00$ per cent).

Keyword: Opinion, Suggestion, intercrop, adoption and Sugarcane

\section{INTRODUCTION}

Sugarcane an important agro-industrial crop plays a pivotal role in Indian economy since it provides raw material to the second largest agro-based industry after cotton. It is major commercial crop of the country and occupies $5.2 \mathrm{~m}$ ha area. According to the Indian Sugar Mill Association (ISMA) area under sugarcane crop in 2015-16 was 53.58 lakh hectares in India [1]. Similarly, Maharashtra, have a 10.6 lakh ha area during same year [2]. Kolhapur district is said to be a major sugarcane growing district having 1,46,295 ha area and average productivity $93.2 \mathrm{t} / \mathrm{ha}$ [3]. In view of changing market scenario, consumers' preferences and global competitions, new income generating opportunities need to be created through crop diversification sugarcane in 'Produce to Product Chain'. This would help in increasing the land utilization efficiency, reducing the production cost, economizing the use of market purchased costly inputs and making plant-ratoon system sustainable.

This intern raises the socio-economic status of small and marginal resource constrained respondents and generates employment especially for rural women and youths. Land being inelastic, sugar industry can no longer stay with extensive cultivation of sugarcane for its future growth. Therefore, importance of intercropping and crop diversification has been recognized profitable and economical for combating the future problems. As sugarcane is planted in wide rows $(75-80 \mathrm{~cm})$ and grows slowly with lateral spread in its early stages of growth and therefore, the inter row spaces remain vacant for three to five months depending on the season of planting [4]. In theory, sugarcane is a crop that offers unique possibilities for intercropping. The plant cane crop takes two to three months to become established during which time food crops can be planted in the interline spaces, to make better use of incident solar energy and rainfall [5]. There is a variety of choices for making a selection of suitable crops which varies from place to place depending upon the season, geographical regions and agro climatic conditions prevailing in different sugarcane growing areas [6]. Since increasing the area under these crops is not possible due to limited availability of agricultural land, the only option is to increase the cropping intensity and crop productivity on the available land. The productivity of land could be enhanced substantially by growing intercrops in the space left between sugarcane rows. Keeping the idea in view, this research was undertaken to study knowledge and adoption of intercropping in sugarcane by the respondents and constraints faced and suggestions made by the respondents. 


\section{Methodology}

The study was conducted purposively in the Hatkanangle, Radhanagari and Bhudharghar tahsils of Kolhapur district which comes under College Development Block, Agriculture College, Kolhapur during the year 2016-2017. Ten villages having maximum area under sugarcane from each tahsils were selected purposively and list of the sugarcane growers was obtained from concern Agriculture Assistant of College Development Block.

Table 1: Selection of villages

\begin{tabular}{|c|c|c|c|}
\hline \multirow{2}{*}{ Sr. } & \multicolumn{3}{|c|}{ Tahsils } \\
\cline { 2 - 4 } No. & Hatkanagale & Radhanagari & Bhudharghar \\
\hline 1 & Padali & Kapileshwar & Gargoti, \\
\hline 2 & Talsande & Titve & Salpewadi, \\
\hline 3 & Wathar & Chandre & Shindewadi, \\
\hline 4 & Ghunaki & Waghapur & Phanaswadi,. \\
\hline 5 & Alate & Arjunwada & Ambawane, \\
\hline 6 & Male & Turambe & Kalnakwadi, \\
\hline 7 & Sajani & Mangoli & Khanapur, \\
\hline 8 & Kabnoor & Talashi & Hanbarwadi \\
\hline 9 & Sambhapur & Kasarwada & Sonali \\
\hline 10 & Top & Admapur & Shindewadi \\
\hline
\end{tabular}

From each selected villages, 5 respondents were selected randomly. The respondents were interviewed with the help of structured interview schedule personally. In all 150 respondents were interviewed for this study. The extent of adoption of innovations/recommendations was studied. The constraints in adoption of technologies and suggestions of respondents for efficient use of innovations were also studied. Ex-Post Facto Design was used. The data were tabulated and processed through the primary and secondary tables. The statistical tools like frequency, percentages, and means of the averages was used for interpreting the data and inferences are drawn.

\section{Results and discussion}

Sugarcane information: From Table 2 it is found that three-fourth (76.00 per cent) of the respondents preferred pre-seasonal season for sugarcane plantation.

Table 2 Distributions of respondents according to sugarcane information.

\begin{tabular}{|c|c|c|c|}
\hline \multirow{2}{*}{ Sr. No. } & \multirow{2}{*}{ Information of Sugarcane cultivation } & \multicolumn{2}{|c|}{ No. of respondents $(\mathrm{N}=\mathbf{1 5 0})$} \\
\hline & & Number & Percentage \\
\hline \multirow{5}{*}{1} & Resear Season & d & 0 \\
\hline & Adsali & 280 & 18.67 \\
\hline & Preseasonal elopitie & It: 114 & 76.00 \\
\hline & 90 & 21 & 14.00 \\
\hline & Ratoon & 2 & 1.33 \\
\hline \multirow{4}{*}{2} & Varieties & e & 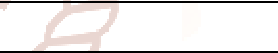 \\
\hline & Phule -265 & 24 & 16.00 \\
\hline & COM- 86032 & 105 & 70.00 \\
\hline & CO-92005 & 60 & 40.00 \\
\hline \multirow{4}{*}{3} & Production $(\mathrm{t}$ & ha.) & \\
\hline & Less than 100 & 61 & 40.67 \\
\hline & $101-150 \cup$ & 53 & 35.33 \\
\hline & More than 151 & 51 & 34.00 \\
\hline \multirow{6}{*}{4} & Experience ( & & \\
\hline & Up to 5 & 22 & 14.67 \\
\hline & 6 to 10 & 29 & 19.33 \\
\hline & 10 to 20 & 65 & 43.33 \\
\hline & 21 to 30 & 22 & 14.67 \\
\hline & 31 and above & 12 & 8.00 \\
\hline \multirow{6}{*}{5} & Income from sugar & ane (Rs.) & \\
\hline & Up to 1.5 lakh & 74 & 49.33 \\
\hline & $1.51-3.00 \mathrm{lakh}$ & 52 & 34.67 \\
\hline & 3.01- 5.00 lakh & 16 & 10.67 \\
\hline & 5.01 and above & 8 & 5.33 \\
\hline & & 150 & 100.00 \\
\hline
\end{tabular}


It may be due to the flood situation and adsali season mostly affected by that situation. It was also observed that respondents from river basin do not follows the adsali and prefers only preseasonal and suru seasons. Till today majority of farmers preferred COM-86032 cultivar of sugarcane. Nearly 44.00 percent of respondents grow sugarcane crop since 10 to 20 years and half per cent of respondents obtained annual income upto Rs.1.5 lakh rupees from sugarcane crop.
Only 5.33 per cent of respondents were obtained income of Rs. 5.01 lakh and above. It may be due to the more area under sugarcane crop.

Intercrop cultivation: Regarding intercrops grown in sugarcane, majority of respondents (65.33 per cent) were taken intercrops in rabi season followed by kharif (22.00 per cent) and summer (14.00 per cent).

Table3 Distribution of respondents according to intercrop cultivation.

\begin{tabular}{|c|c|c|c|}
\hline \multirow{2}{*}{ Sr. No } & \multirow{2}{*}{ Information of Sugarcane cultivation } & \multicolumn{2}{|c|}{ No. of respondents $(\mathrm{N}=150)$} \\
\hline & & No. & $\%$ \\
\hline \multirow{4}{*}{1} & \multicolumn{3}{|l|}{ Season } \\
\hline & Kharif & 33 & 22.00 \\
\hline & Rabi $\mathrm{Cr}$ & 98 & 65.33 \\
\hline & Summer & 21 & 14.00 \\
\hline \multirow{4}{*}{2} & i. Cereals (Wheat, Maize) & 45 & 30.00 \\
\hline & ii. $\quad$ Pulses (Gram, Masura) & 51 & 34.00 \\
\hline & Oil seeds - (Ground nut, Soybean and Sesamum) & 48 & 32.00 \\
\hline & Vegetables (Onion, Cabbage, Methi Coriander) & 102 & 68.00 \\
\hline \multirow{7}{*}{3} & Experience (yrs) Onal Journall & 8 & \\
\hline & Up to 5 & 57 & 38.00 \\
\hline & 6 to 10 & 56 & 37.33 \\
\hline & 10 to 20 search and & 32 & 21.33 \\
\hline & 21 to30 & 5 & 3.33 \\
\hline & 31 and above 30 pitient & 0 & 0.00 \\
\hline & 5 & 150 & 100.00 \\
\hline \multirow{6}{*}{4} & Income from intercrop (Rs.) & +0 & \\
\hline & Up to $25000 /-$ & 90 & 60.00 \\
\hline & 25001 to $35,000 /-$ & 42 & 28.00 \\
\hline & $35001-45,000 /-$ & 8 & 5.33 \\
\hline & $45,001 /-$ and above & 10 & 6.67 \\
\hline & 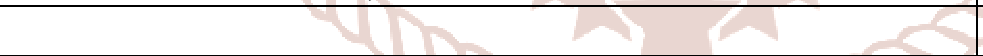 & 150 & 100.00 \\
\hline \multirow[t]{5}{*}{5} & Purpose & & \\
\hline & Secondary income source & 72 & 48.00 \\
\hline & Fulfilment of sugarcane cost & 57 & 38.00 \\
\hline & Domestic use & 92 & 61.33 \\
\hline & Surplus income in short period & 74 & 49.33 \\
\hline
\end{tabular}

Respondents were preferred the vegetable (68.00 per cent) as a intercrops in sugarcane. This agrees with the findings of [7] in Mauritius in intercropping of potato with maize. Three-fifth of respondents $(60.00$ per cent) had income up to Rs. 25,000/- from intercrop followed by Rs. 25001/- to 35,000/- (28.00 per cent). More than 60.00 per cent of respondents taking intercrops for domestic purpose followed by surplus income in short period (49.33 per cent), secondary income source $(48.00$ per cent $)$ and fulfilment of sugarcane cultivation cost (38.00 per cent).

Adoption of intercrops: In relation to complete adoption (Table 5), all respondents were mentioned there was no any extra provision of intercultural operations, irrigation management, crop protection, harvest time and marketing in local market. In short 
all intercrops can be yielded successfully on same intercultural and irrigation management of sugarcane. More than 75.00 per cent of respondents adopted seed as source of propagation of intercrops, placement of seeds/ seedlings at centre of ridges and furrows and intercrops fulfilled their lifecycle on fertilizers which were given to sugarcane that means saving of fertilizers can be possible. Most of the respondents 98.00 per cent were not adopted biological seed treatments and separate irrigation and fertilizer management of intercrops.

Table5. Distributions of respondents according to adoption about intercrop.

\begin{tabular}{|c|c|c|c|c|}
\hline \multirow{2}{*}{ Technologies } & \multicolumn{4}{|c|}{ Adoption ( $\mathrm{N}=150)$} \\
\hline & Complete & $\%$ & No & $\%$ \\
\hline \multicolumn{5}{|c|}{ Method of propagation } \\
\hline Seed & 116 & 77.33 & 34 & 22.67 \\
\hline Seedlings & 60 & 40.00 & 90 & 60.00 \\
\hline \multicolumn{5}{|c|}{ Seed treatment } \\
\hline Chemical & 31 & 20.67 & 119 & 79.33 \\
\hline Biological & 3 & 2.00 & 147 & 98.00 \\
\hline \multicolumn{5}{|c|}{ Placement of seed/seedlings } \\
\hline Centre of ridges & $115 / \mathrm{C}$ & 76.67 & 35 & 23.33 \\
\hline Paired row & 35 & 23.33 & 115 & 76.67 \\
\hline \multicolumn{5}{|c|}{ Fertilizer management } \\
\hline Separate provision & 26 & 17.33 & 124 & 82.67 \\
\hline Sufficient fertilizers of sugarcane & 124 & 82.67 & 26 & 17.33 \\
\hline 6e 9 & tivation & & 2 & 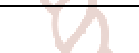 \\
\hline Separate provision & 0 & 0.00 & 150 & 100.00 \\
\hline Sufficient of sugarcane & 150 & 100.00 & 0 & 0.00 \\
\hline \multicolumn{5}{|c|}{ Irrigation management } \\
\hline Separate provision esea & Chonc & 0.00 & 150 & 100.00 \\
\hline Sufficient of sugarcane & 150 & 100.00 & 0 & 0.00 \\
\hline \multicolumn{5}{|c|}{ Crop protection } \\
\hline Separate provision & 0 & 0.00 & 150 & 100.0 \\
\hline Sufficient of sugarcane & 150 & 100.00 & 0 & 0.00 \\
\hline Extra provision for vegetable & 23 & 15.33 & 127 & 84.67 \\
\hline \multicolumn{5}{|c|}{ Harvesting time } \\
\hline In time & 150 & 100.00 & 0 & 0.00 \\
\hline after time & 0 & 0.00 & 150 & 100.0 \\
\hline \multicolumn{5}{|c|}{ method of harvesting } \\
\hline Cutting & 46 & 30.67 & 104 & 69.33 \\
\hline Uprooting & 50 & 33.33 & 100 & 66.67 \\
\hline Picking & 102 & 68.00 & 48 & 32.00 \\
\hline \multicolumn{5}{|c|}{ Marketing } \\
\hline Local market & 150 & 100.00 & 0 & 0.00 \\
\hline Weekly bazar & 37 & 24.67 & 113 & 75.33 \\
\hline
\end{tabular}

Opinion about intercrops - It is observed from table 6 that the all the respondents agreed with intercrops gave extra income. Majority of the respondents mentioned there was no any harmful effect of intercrop on main crop (98.67 per cent), intercrops helps in maintain soil fertility (96.67 per cent), availability of fresh vegetables (94.67 per cent), intercrops gives income in short period (91.33 per cent). Opinion of the respondents about intercrops in sugarcane is fulfils the expenditure cost of sugarcane (81.33 per cent), daily economic need of family (73.33 per cent), weed irradiations (61.33 per cent) and availability of green fodder (56.00 per cent). 
International Journal of Trend in Scientific Research and Development (IJTSRD) ISSN: 2456-6470

Table6. Distributions of respondents according to their opinions about intercrop

\begin{tabular}{|c|c|c|}
\hline \multirow{2}{*}{ Opinions } & \multicolumn{2}{|c|}{$\begin{array}{c}\text { No. of } \\
\text { respondents } \\
(\mathbf{N}=150)\end{array}$} \\
\cline { 2 - 3 } Extra income & 150 & 100.00 \\
\hline No. & Per cent \\
\hline No any effect on main crop & 148 & 98.67 \\
\hline Increases soil fertility & 145 & 96.67 \\
\hline $\begin{array}{c}\text { Availability of fresh } \\
\text { vegetables }\end{array}$ & 142 & 94.67 \\
\hline Income in short period & 137 & 91.33 \\
\hline $\begin{array}{c}\text { Fulfilment of expenditure cost } \\
\text { of main crop }\end{array}$ & 122 & 81.33 \\
\hline $\begin{array}{c}\text { Fulfilment of daily economic } \\
\text { need of family }\end{array}$ & 110 & 73.33 \\
\hline Weed eradication & 92 & 61.33 \\
\hline Availability of green fodder & 84 & 56.00 \\
\hline
\end{tabular}

Constraints: It is observed that most of the respondents were facing constraints namely increase in earthing-up period (98.00 per cent), first earthingup and intercultural operations are not possible (94.00 per cent each), possibility of pest and disease attack (82.67 per cent) and lack of post emergence herbicide in sugarcane (73.33 per cent). Similar findings were obtained by [8] in which they mentioned constraints of earthing-up was not possible.

Table7. Constraints faced by the respondents.

\begin{tabular}{|c|c|c|}
\hline \multirow{2}{*}{ Constraints } & \multicolumn{2}{|c|}{$\begin{array}{c}\text { No. of respondents } \\
(\mathbf{N}=150)\end{array}$} \\
\cline { 2 - 3 } & Number & $\%$ \\
\hline $\begin{array}{c}\text { Increase period of earthing- } \\
\text { up }\end{array}$ & 147 & 98.00 \\
\hline $\begin{array}{c}\text { First earthing-up is not } \\
\text { possible }\end{array}$ & 141 & 94.00 \\
\hline $\begin{array}{c}\text { Obstacles in interculturing } \\
\text { operations }\end{array}$ & 141 & 94.00 \\
\hline $\begin{array}{c}\text { Possibility of pest and } \\
\text { disease attack }\end{array}$ & 124 & 82.67 \\
\hline $\begin{array}{c}\text { Post emergence herbicides } \\
\text { are not possible to apply. }\end{array}$ & 110 & 73.33 \\
\hline $\begin{array}{c}\text { Lack of labour } \\
\text { Spacing of emitters changes } \\
\text { according to intercrop }\end{array}$ & 78 & 52.00 \\
\hline
\end{tabular}

Suggestions: Majority of the respondents suggested growing of short duration intercrop ( 88.00 per cent), short duration varities of sugarcane is needed in adsali planting (80.67 per cent), availability of common agril. intercultural implements (79.33 per cent) and need of mechainization (46.00 per cent).

Table 8. Suggestions made by respondents for effective intercrop in sugarcane

\begin{tabular}{|c|c|c|}
\hline \multirow{2}{*}{ Suggestions } & \multicolumn{2}{|c|}{$\begin{array}{r}\text { No. of respondents } \\
\text { (N=150) }\end{array}$} \\
\cline { 2 - 3 } & No. & Per cent \\
\hline $\begin{array}{c}\text { There should be short } \\
\text { duration intercrop crop }\end{array}$ & 132 & 88.00 \\
\hline $\begin{array}{c}\text { There should be short } \\
\text { duration sugarcane variety in } \\
\text { adsali season }\end{array}$ & 121 & 80.67 \\
\hline $\begin{array}{c}\text { Common agril. Implements } \\
\text { should be available to } \\
\text { interculture operations for } \\
\text { sugarcane \& intercrop }\end{array}$ & 119 & 79.33 \\
\hline $\begin{array}{c}\text { Technology regarding weed } \\
\text { control should be developed }\end{array}$ & 92 & 61.33 \\
\hline $\begin{array}{c}\text { Instead of labour, there } \\
\text { should be machanization }\end{array}$ & 69 & 46.00 \\
\hline
\end{tabular}

\section{Conclusions}

Most of the farmers were grown sugarcane in preseasonal season followed by adsali (18.67 per cent) with majority of farmers preferred $C O M$ 86032 cultivar of sugarcane followed by $\mathrm{Co}$ 92005 (40.00 per cent) and Phule-265 (16.00 per cent).

Majority of responds (65.33 per cent) were taken intercrops in rabi season.

Majority of respondents were preferred the vegetable (68.00 per cent) and obtained income up to Rs. 25,000/- from intercrop (60.00 per cent)

All respondents were mentioned there was no any extra provision of intercultural operations, irrigation management, crop protection, harvest time and produce marketing in local market.

All the respondents agreed with intercrops gave extra income.

$>$ It is observed that most of the respondents were remarked constraints of increase in earthing-up period (98.00 per cent) and first earthing-up and intercultural operations are not possible $(94.00$ per cent).

$>$ Majority of the respondents suggested growing of short duration intercrop (88.00 per cent), need of short duration verities of sugarcane in adsali planting (80.67 per cent), and common agril. Intercultural implements (79.33 per cent) and need of mechanization (46.00 per cent). 


\section{Recommendation}

It was observed that majority of respondents grows vegetables and nourishes it without affecting sugarcane crop in which they earns extra income and minimize the production cost of sugarcane therefore it is recommended that intercrop of vegetable specially onion are beneficial in preseasonal sugarcane crop. For that State Agricultural Department and Krishi Vigyan Kendra should emphasize on adoption of onion crop in sugarcane crop as an intercrop.

\section{References}

1. Anonymous, 2015a. Economic Survey of Maharashtra 2014-15. Directorate of Economics and Statistics, Planning Dapartment, Government of Maharashtra, Mumbai: 78-79.

2. Anonymous, 2015b. Sugar industries in India. Indian Sugar Mills Association report May-2015.

3. Anonymous, 2016. Estimated area, production and productivity of Sugarcane in Kolhapur district. Districts of India.
4. Parsons M. J. 2003. Successful intercropping of sugarcane. Proc S Afr Sug Technol Ass (2003) 7: 77-98.

5. Saxena M C (1972). Concept of parallel multiple cropping. Proceedings of a Symposium on multiple cropping, New Delhi. Indian Society of Agronomy.

6. Pandey M B and Shukla S K (2000). Quality and productivity of promising sugarcane (Saccharum officinarum) genotypes under various planting seasons and nitrogen levels in sub-tropical India. Indian J Agron 45(3): 617-623.

7. Ng Kee Kwong $\mathrm{K}$ F, Umrit $\mathrm{G}$ and Deville $\mathrm{J}$ (1996). Nitrogen fertilization of sugarcane in an intercropping system with maize and potato in the humid tropical climate of Mauritius. Experimental Agriculture 32(2): 213-218.

8. Tarde V. J., S. D. Bhingardeve, B. T. Kolgane and K. V. Gurav. 2016. A study on Knowledge and Adoption of intercrop in sugarcane from Kolhapur District. Report submitted to the Research Review Committee. M. P. K. V., Rahuri. 